\title{
Bone ageing and HIV
}

Patrick W Mallon

From $16^{\text {th }}$ International Symposium on HIV and Emerging Infectious Diseases

Marseille, France. 24-26 March 2010

As HIV-infected patients live longer they are experiencing diseases normally associated with ageing, sometimes at higher frequency and at younger ages than expected. Low bone mineral density (BMD) and osteoporosis is one example. Rates of low BMD are high in HIV-infected patients and fracture rates occur more commonly and at a younger age than the general population. Factors thought to contribute to low BMD in HIV include HIV infection itself, exposure to antiretroviral therapy (ART) and over-representation of traditional risk factors (such as smoking, hypogonadism and low body mass index) for low BMD in HIV-infected populations. Current evidence suggests that patients lose BMD after ART initiation and, to some extent, with switch in ART. Rates of BMD loss appear higher when protease inhibitors or some NRTI are used as part of the initial ART regimen. This presentation will outline current data on low BMD in HIV, discuss ways of monitoring for low BMD and current approaches to management of this common condition.

Published: 11 May 2010

Submit your next manuscript to BioMed Central and take full advantage of:

- Convenient online submission

- Thorough peer review

- No space constraints or color figure charges

- Immediate publication on acceptance

- Inclusion in PubIMed, CAS, Scopus and Google Scholar

- Research which is freely available for redistribution

Submit your manuscript at www.biomedcentral.com/submit 